\title{
Stewardship Success: How Community Group Dynamics Affect Urban Street Tree Survival and Growth
}

\author{
Emily Jack-Scott, Max Piana, Blake Troxel, Colleen Murphy-Dunning, and Mark S. Ashton
}

\begin{abstract}
Over the last two decades, there has been a substantial increase in street tree plantings across the United States. Many cities have set ambitious planting goals, relying on volunteer community groups to meet them. Existing research demonstrates that community stewardship increases the survival of urban street trees. There is a lack of research, however, on how defining characteristics of community groups affect the survival and growth of the trees they plant. This study explores the significance of community group size (\# participants), type (apartment, block watch, church, concerned neighbors, park, public housing, school, and social service), planting longevity (\# years active), experience level (\# trees planted), and neighborhood (geo-political boundaries). Measured for this study were 1393 trees planted from 1995 to 2007, by 134 groups, through the Urban Resources Initiative's Community Greenspace program in New Haven, Connecticut, U.S. There was an overall survival rate of $76 \%$. Highest survival and growth was found among trees planted by groups with more planting experience, greater longevity, and more participants. Higher tree survival and growth was observed when trees were planted by groups working in line with their mission (e.g., park groups in parks). Lowest survival and growth was found among yard trees planted by public housing groups. Existing canopy cover and neighborhood percent homeownership had little effect on survival or growth. This research can offer guidance for city managers by suggesting which planting groups require particular assistance in conducting successful, lasting street tree plantings.

Key Words. Community Forestry; Connecticut; Mean Annual Growth Increment; Mortality; Percent Live Crown; Planting; Stewardship; Urban Ecology; Urban Forestry; Volunteer.
\end{abstract}

Urban trees are important features of city infrastructure and are known to improve air quality, ameliorate summer heat island temperatures, lower cooling costs (McPherson et al. 1994), reduce storm water runoff (Sanders 1984), and increase property values (Anderson and Cordell 1988). They foster neighborhood cohesion by attracting permanent homeowners (Burch and Grove 1993; Zhang et al. 2007) and lowering violence and crime rates (Sullivan and Kuo 1996; Troy et al. 2012). Urban trees also boost cognitive development and function in urban children (Wells 2000; Taylor and Kuo 2011), alleviate stress, improve interpersonal relations, and provide spiritual fulfillment (Dwyer et al. 1992). Urban populations feel, on average, very positively toward street trees-most highly valuing their shade, aesthetics, air quality, and noise amelioration (Lohr et al. 2004).

Despite increasing requests for tree plantings, canopy cover across U.S. cities is in decline (Nowak and Greenfield 2012). Survival of urban street trees has long been a problem, with survival over 50 years as low as $23 \%$ (Foster and Blaine 1978). Urban trees face many obstacles in the urban environment. Generally speaking, 'shortage of funds' is cited by half of ecological stewardship groups as their major obstacle (Svendsen and Campbell 2008), and urban foresters are no exception (McPherson et al. 1997). Three recurring biophysical challenges are: 1) insufficient nutrients, 2) lack of water, and 3) vandalism (Black 1978; Beatty and Heckman 1981; Quigley 2004); all of which can be ameliorated by community and homeowner involvement. It is therefore apparent that in order to augment city-wide canopy cover, urban forest- ers must not only increase the number of new plantings, but also bolster maintenance and survival of existing trees (Luley and Bond 2002; Maco and McPherson 2003; Boyce 2010).

Community group participation has proven integral to meeting these planting and maintenance needs (Dwyer et al. 2000; Conrad and Daoust 2008; Greene et al. 2011). Homeowner inclusion in the planting process can lead to higher empowerment (Westphal 2003) and higher ratings of satisfaction with street trees (Sommer et al. 1994), greater sense of ownership, and improved stewardship (Black 1978; Pagdee et al. 2006). This is a crucial process, as trees have higher rates of survival when stewarded by local community groups (Boyce 2010). Volunteer motivations for planting trees vary. The most commonly reported motives included: a) improving the aesthetics and health of the urban environment, b) community service, c) benefiting youth, and d) a love for planting trees (Westphal 1993; Ryan et al. 2001; Moskell et al. 2010). Volunteers become deeply committed to not only their worksites, but also to other natural spaces in their areas (Ryan et al. 2001).

It is difficult for practitioners to gauge the success of community-driven urban greening projects because progress is often relative for each group (Westphal 2003). Possible indicators of success are longevity (Burch and Grove 1993), sustainability (Florin et al. 1992), and group size (Pagdee et al. 2006; Wagner and Fernandez-Gimenez 2009). These can be influenced by the degree to which members of the group relate to the issue, the cohesion of its members around a mission, the support the group receives from the broader base, and lastly, the group's 
own sense of accomplishment (Abbott 1995; Millar 2003; Lee and Hancock 2011). Little empirical research exists, however, examining the traits of planting groups with successful plantings.

The most easily defined aspect of success is the survival and health of trees planted. Variability in mortality rates across community groups is complex, with hidden causes easily overlooked (Abbott 1995). Nowak et al. (1990) found that mortality was highest in neighborhoods with high levels of unemployment, around public housing and apartment buildings (low homeownership), but not associated with race. Dwyer et al. (2002) highlighted the need for further research into the roles of community groups, government agencies, and non-profits in street tree survival.

The main objective of this study was to provide empirical data on the role of community planting groups in the survival and growth of urban street trees. Community group dynamics such as size, longevity, type (park, public housing, block watch, and more), planting experience (number of trees planted previously), and related neighborhood traits (existing canopy cover, and homeownership rate) were examined. Based on existing research regarding volunteer motivations and group cohesion, it was hypothesized that higher rates of growth and survival would be observed when planted by groups with larger group size, more tree planting experience, and greater group longevity. The same was also hypothesized for groups in neighborhoods with greater existing canopy cover and homeownership rates. Finally, groups with missions in line with urban greening (namely park groups) were hypothesized to have greater growth and survival than those without (i.e., public housing and social service groups).

\section{METHODS}

\section{Site Description}

Trees surveyed were planted between 1995 and 2007, through the Urban Resource Initiative's Community Greenspace program in New Haven, Connecticut. New Haven is located along the northern coast of the Long Island Sound, an estuary of the Atlantic Ocean in southern New England. New Haven has an area of $48.9 \mathrm{~km}^{2}$ and an elevation of 10 $\mathrm{m}$. It has a temperate climate, with average summer temperatures in July at $23.3^{\circ} \mathrm{C}$ and average winter temperatures in January at $-1.4^{\circ} \mathrm{C}$; receiving a total of $116.8 \mathrm{~cm}$ of rain at a steady rate throughout the year. It has a citywide average tree cover of 38\% (Pelletier and O'Neil-Dunne 2009).

The Urban Resources Initiative (URI) is a non-profit organization that has planted trees in New Haven since it was established in 1991. Its Community Greenspace program works with groups comprised of interested residents and volunteers on group-initiated planting sites. Groups carry out planting and maintenance with URI tools, planting materials (including trees), mulch, and technical assistance in the form of a trained intern from the Yale School of Forestry and Environmental Studies. Intern reports are compiled each year, chronicling all tree plantings and locations, forming a unique and valuable database of community-planted street trees. After a number of active years, groups may opt into a designated stewardship program called the Emeritus program, in which they may discontinue planting trees but continue to receive support in the form of tools, mulch, and intern consultations.

\section{Sampling Design and Data Collection}

Reports indicate that between 1995 and 2007, 134 of URI's Greenspace groups planted a total 1560 trees. In the summer and autumn of 2011, these trees were located and measured for survival and growth indices, including diameter at breast height $(\mathrm{DBH})$ and percent live crown. DBH was divided by the number of years since planting (approximate age of the tree) in order to calculate mean annual growth increment. Percent live crown (the length along the main stem from top height of the tree to the lowest living branch divided by the total height of the tree) was measured using the percent scale on a clinometer (Suunto PM-5, Forestry Supplies, Jackson, Mississippi, U.S.). Both indices can be used to evaluate tree vigor and health, with higher rates and percentages indicating healthier trees. Each planting site was also noted as a street (curbside), yard, park, or vacant lot site-and results were analyzed within each site type.

Community group data was gathered from annual intern reports, including group size, group planting longevity, group type, group focus, and geo-political neighborhood. Group size signified the average maximum number of volunteers recorded per planting season as having participated with each community group. Group longevity represented the number of planting seasons each group participated in the Greenspace program. Group experience was measured by how many trees the group had planted, both during each planting season and overall. Group types were categorized as apartment, block watch, business, church, neighborhood management team, neighborhood resident, park, public housing, school, or social service/non-profit. Based on geo-political neighborhood boundaries, existing tree canopy cover was determined for each group using aerial imagery and GIS. Homeownership rates were also determined by census block group for each community group using the national decadal 2000 Census.

\section{Statistical Analysis}

Statistical analysis was done using $\mathrm{R}$ statistical software and language (Crawley 2007). Trees were analyzed within site type so that street trees were compared to street trees, yard to yard, park to park, and vacant lot to vacant lot. This was done in order to minimize potentially covariate biophysical factors (such as available growing space), and highlight the targeted social factors affecting tree survival and growth. Mortality data was analyzed using logistic regression (Takano et al. 2002), and multiple linear regressions were used to analyze mean annual growth increment and percent live crown data (Tomé and Burkhardt 1989). Mean annual growth increment data was normalized using a log transformation. Percent live crown data was normalized with an arcsine-square root transformation (street, yard, and park trees), and a log transformation (vacant lot trees) to account for skewed values in the $70 \%-80 \%$ range. A forward selection procedure was done to isolate significant factors, used in regression trees as a visual aid to determine significant interaction effects. Explanatory variables included tree age, tree function (shade versus ornamental), community group planting longevity, group planting experience, group type, existing neighborhood canopy cover, and census block group percent homeownership.

\section{RESULTS}

A total of 1393 trees $(89 \%)$ were located and measured. The remaining 167 trees not found were either removed due to con- 
struction or planted in unrecorded locations. These sites were excluded from statistical analysis as no data was available for them.

\section{Survival}

Trees across all thirteen age groups had an average survival rate of $74 \%$ (1029 out of 1393 trees) and an average age of 9.2 years (post-planting). By site type, street trees had an average survival rate of $77.5 \%$ (average age 9 years), yard trees $58.6 \%$ (10.1 years), park trees $80.1 \%$ ( 7.9 years), and vacant lot trees $73.1 \%$ (9.8 years). Logistic regression revealed significant factors affecting survival were tree age, group experience, group longevity, group size, group type, and percent homeownership (street tree Equivalent R-squared $=0.0924$, yard tree Equivalent $\mathrm{R}$-squared $=0.1364$, park tree Equivalent $\mathrm{R}$-squared $=$ 0.2568 , vacant lot tree Equivalent $R$-squared $=0.1402)($ Table 1$)$.

Survival rates dropped with tree age for street $(p=0.0061)$, yard $(\mathrm{p}<0.0001)$, and park trees $(\mathrm{p}=0.0008)$. There was not, however, a significant change in survival rate among vacant lot trees with age. Group experience (\# trees planted) was positively correlated with survival within all planting sites: street trees (p $=0.0088)$, yard trees $(\mathrm{p}=0.0398$ for apartment groups only $)$, park trees $(\mathrm{p}=0.0462$ in areas with higher \% homeownership), and vacant lot trees $(\mathrm{p}=0.0108)$. Group size correlated positively with survival for vacant lot trees, as well as park trees $(\mathrm{p}=$ 0.0290 ), but only for those planted by park groups; otherwise, group size actually had a significantly negative correlation with survival among park trees. Group longevity was only significant for street trees, with increasing survival the longer groups were active in the Emeritus stewardship program $(\mathrm{p}=0.0418)$. The interaction effect between tree age and group longevity was actually negatively correlated with survival for street trees (0.0233).

Group type was also a significant factor affecting survival. Public housing $(\mathrm{p}=0.0003)$ and social service/non-profit $(\mathrm{p}=$ $0.0457)$ groups had lower survival among their yard trees than did experienced apartment groups $(p=0.0398)$. As for trees planted in parks, large park groups had higher survival than other group types $(p=0.0290)$. Finally, percent homeownership within the census block group of each planting group proved significant in some instances. In general, park trees $(\mathrm{p}=$ $0.0278)$ and vacant lot trees $(\mathrm{p}=0.0042)$ in areas with higher percent homeownership had lower survival. However, as groups gained more experience in areas with high percent homeownership, their park tree survival actually went up significantly $(\mathrm{p}=0.0462)$. Shade versus ornamental, and existing percent canopy cover did not significantly correlate with tree survival.

\section{Growth Indices}

Growth was measured through mean annual growth increment and percent live crown. Multiple linear regressions indicated tree age, tree function (shade versus ornamental), group planting experience, group longevity, group size, and group type significantly affected tree growth

Mean annual growth increment was primarily correlated with tree age, tree function, group type, group size, and group longevity ( street tree Adjusted R-squared $=0.2031$, yard tree Adjusted Rsquared $=0.3491$, park tree Adjusted R-squared $=0.4728$, vacant lot tree Adjusted R-squared $=0.2702$ ) (Table 2). Among all site types, mean annual growth increment negatively correlated with tree age (street $p<0.0001$, yard $p=0.0002$, park $p<0.0001$, and vacant lot $p<0.0001)$. Mean annual growth increment was higher in shade trees for street $(p=0.0003)$, yard $(p<0.0001)$, and vacant lot $(\mathrm{p}=0.0080)$ trees, but was actually lower among those in parks $(p=0.0004)$. After accounting for covariance with tree age, higher group longevity significantly correlated with higher mean annual growth increment among street trees $(\mathrm{p}=0.0231)$ yard trees $(p=0.0031)$, and vacant lot trees $(p=0.0509)$. Groups with more participants also had higher mean annual growth increment among street $(\mathrm{p}=0.0056)$ and yard $(\mathrm{p}<0.0001)$ trees Group experience planting trees had a significantly positive effect on mean annual growth increment only in vacant lot trees $(\mathrm{p}=$

Table 1. Significant social and physical factors affecting street tree survival. Significance codes: $0\left({ }^{* * *}\right), 0.001\left(^{* *}\right), 0.01\left({ }^{*}\right)$. Interaction effects are noted (+).

\begin{tabular}{|c|c|c|}
\hline Survival regression coefficients & Estimate & $P$-value \\
\hline \multicolumn{3}{|l|}{ Street tree survival (Equivalent R-squared $=0.0924, \mathrm{AIC}=820.77$ ) } \\
\hline Tree age & -0.1032 & $0.0061 * *$ \\
\hline Group experience (\# trees planted during planting year) & 0.0542 & $0.0088 * *$ \\
\hline Group emeritus longevity (\# years in Emeritus program) & 0.1724 & $0.0418 *$ \\
\hline Group longevity (\# years as of planting year) + Tree age & -0.0307 & $0.0233 *$ \\
\hline \multicolumn{3}{|l|}{ Yard tree survival $($ Equivalent R-squared $=0.1364, \mathrm{AIC}=319.74)$} \\
\hline Tree age & -0.1931 & $<0.0001 * * *$ \\
\hline Public housing groups & -1.5485 & $0.0003 * * *$ \\
\hline Social service/non-profit groups & -0.7858 & $0.0457 *$ \\
\hline Apartment groups + Group experience (total trees planted) & 0.1550 & $0.0398 *$ \\
\hline \multicolumn{3}{|l|}{ Park tree survival (Equivalent R-squared $=0.2568, \mathrm{AIC}=143.06$ ) } \\
\hline Tree age & -0.4799 & $0.0008 * * *$ \\
\hline Group experience (total \# trees planted) & -0.3669 & $0.0413 *$ \\
\hline Group size (\# participants during planting year) & -0.2040 & $0.0089 * *$ \\
\hline$\%$ Homeownership (in Census Block Group) & -0.1896 & $0.0278 *$ \\
\hline Group experience $+\%$ Homeownership & 0.0073 & $0.0462 *$ \\
\hline Group size + Park groups & 0.1797 & $0.0290 *$ \\
\hline \multicolumn{3}{|l|}{ Vacant lot tree survival $($ Equivalent $\mathrm{R}$-squared $=0.1402, \mathrm{AIC}=142.08)$} \\
\hline Group experience (\# trees planted during planting year) & 0.1257 & $0.0108 *$ \\
\hline Group size (\# participants during planting year) & 0.0817 & $0.0257 *$ \\
\hline \% Homeownership (in Census Block Group) & -0.0568 & $0.0042 * *$ \\
\hline
\end{tabular}


0.0263). Neighborhood resident groups had higher mean annual growth in their street trees $(\mathrm{p}=0.0063)$, but lower mean annual growth in their vacant lot trees $(\mathrm{p}=0.0126)$. Social service/nonprofit groups had higher yard tree mean annual growth increment than other groups $(\mathrm{p}=0.0017)$. Street trees in areas with higher existing percent canopy cover had higher mean annual growth increment rates $(\mathrm{p}=0.0055)$, while ornamental park trees in areas of high existing canopy cover have lower $(\mathrm{p}<0.0001)$.

Percent live crown was similarly affected primarily by tree age, treefunction, group experience, group size, grouplongevity, and group type (street tree Adjusted R-squared = 0.0431, yard tree Adjusted R-squared $=0.1398$, park tree Adjusted $\mathrm{R}$-squared $=0.2992$, vacant lot tree Adjusted R-squared $=$ 0.2004 ) (Table 3 ). Older trees had higher live crown percentages among street trees $(p<0.0001)$, yard trees $(p=0.0022)$, and park trees $(\mathrm{p}=0.0506)$, but not among vacant lot trees. Ornamental trees had significantly lower percent live crown than shade trees in street $(\mathrm{p}=0.0384)$, and yard $(\mathrm{p}=0.0166)$ site types. When paired with tree age, shade trees in parks had higher percent live crown as well $(\mathrm{p}=0.0506)$. Group planting experience was positively correlated with percent live crown among street $(\mathrm{p}=0.0577)$ and vacant lot $(\mathrm{p}=0.0117)$ trees, but negatively correlated in park trees $(p=0.0315)$. Group longevity was altogether negatively correlated with percent live crown among yard trees $(\mathrm{p}=0.0004)$, but as trees aged group longevity proved positively correlated with percent live crown $(\mathrm{p}=0.0022)$. Group longevity was also positively correlated with park tree percent live crown $(p<0.0001)$. Group size was negatively correlated with percent live crown in yard trees $(p=0.0135)$, but positively with that of park trees $(p=0.0005)$. Among street trees, neighborhood resident groups had higher percent live crown measures $(p=0.0093)$, while social service/non-profit had lower measures $(\mathrm{p}=$
0.0405). Among vacant lots, on the other hand, social service/ non-profits planted trees with significantly higher percent live crown $(\mathrm{p}=0.0037)$ than did park groups $(\mathrm{p}=0.0181)$.

\section{DISCUSSION}

Overall, social factors have a relatively small impact on urban tree survival and percent live crown with R-squared values ranging from 0.0924 (street trees) to 0.2568 (park trees), and from 0.0431 (street trees) to 0.2992 (park trees), respectively. Slightly more of the variability in mean annual growth increment could be accounted for by social factors with R-squared values from 0.2031 (street trees) to 0.4728 (park trees). And yet, even those R-squared values include tree age as well as tree function (shade versus ornamental), which in some analyses were highly significant and influential factors. Additional investigation into the influence of biophysical factors on tree survival and growth was beyond the scope of this study, but is encouraged. Nevertheless, there are notable significant social factors that impact urban tree health, an understanding of which can offer insight into extending community investment in urban forests.

Firstly, group experience played a prominent role in many regressions as a predictor for improved survival and percent live crown (for street, park, and vacant lot trees). Interestingly, group longevity did not impact tree survival as much as mean annual growth increment and percent live crown, with significantly improved growth in trees of all four site types (after accounting for colinearity with tree age). This validates work by Burch and Grove (1993) that pointed to the importance of group longevity. On the whole, groups with more participants also demonstrated improved tree survival and growth, with exceptions in park tree survival (when planted by non-park

Table 2. Significant social and biophysical factors affecting variation in mean annual growth increment of sampled street trees. Significance codes: $0\left({ }^{* *}\right), 0.001\left(^{* *}\right), 0.01\left(^{*}\right)$. Interaction effects are noted $(+)$.

\begin{tabular}{|c|c|c|}
\hline Mean annual growth increment regression coefficients & Estimate & $P$-value \\
\hline $\begin{array}{l}\text { Street tree mean annual increment (Adjusted R-squared =0.2031) } \\
\text { Tree age } \\
\text { Shade trees } \\
\text { Neighborhood resident groups } \\
\text { Group size (\# participants during planting year) } \\
\text { Existing \% canopy cover } \\
\text { Tree age + Group longevity (total \# years active) }\end{array}$ & $\begin{array}{l}-0.04911 \\
0.1025 \\
0.2028 \\
0.0058 \\
0.0033 \\
0.0031\end{array}$ & $\begin{array}{l}<0.0001 * * * \\
0.0003 * * * \\
0.0063 * * \\
0.0056 * * \\
0.0055 * * \\
0.0231 *\end{array}$ \\
\hline $\begin{array}{l}\text { Yard tree mean annual increment (Adjusted R-squared = 0.3491) } \\
\text { Tree age } \\
\text { Shade trees } \\
\text { Group longevity (\# years active as of planting year) } \\
\text { Group size (average \# participants) } \\
\text { Social service/non-profit groups } \\
\text { Group longevity + Tree age }\end{array}$ & $\begin{array}{r}-0.0654 \\
0.3613 \\
-0.1457 \\
0.0231 \\
0.3244 \\
0.0170\end{array}$ & $\begin{array}{r}0.0002 * * * \\
<0.0001 * * * \\
0.0038 * * \\
<0.0001 * * * \\
0.0017 * * \\
0.0031 * *\end{array}$ \\
\hline $\begin{array}{l}\text { Park tree mean annual increment (Adjusted R-squared = 0.4728) } \\
\text { Tree age } \\
\text { Ornamental trees } \\
\text { Ornamental trees + Existing \% canopy cover }\end{array}$ & $\begin{array}{r}-0.0658 \\
0.5840 \\
-0.0280\end{array}$ & $\begin{array}{r}<0.0001 * * * \\
0.0004 * * * \\
<0.0001 * * *\end{array}$ \\
\hline $\begin{array}{l}\text { Vacant lot tree mean annual increment (Adjusted R-squared }=0.2702 \\
\text { Tree age } \\
\text { Shade trees } \\
\text { Group experience (\# trees planted as of planting year) } \\
\text { Group longevity (total \# years active) } \\
\text { Neighborhood resident groups }\end{array}$ & $\begin{array}{r}-0.0927 \\
0.2407 \\
0.0208 \\
0.0571 \\
-0.2650\end{array}$ & $\begin{array}{l}<0.0001 * * * \\
0.0080 * * \\
0.0263 * \\
0.0509 \\
0.0126 *\end{array}$ \\
\hline
\end{tabular}


Table 3. Significant social and biophysical factors affecting percent live crown of street trees. Significance codes: $0\left({ }^{* * *}\right), 0.001$ $\left({ }^{* *}\right), 0.01\left(^{*}\right)$. Interaction effects are noted $(+)$.

\begin{tabular}{|c|c|c|}
\hline Percent live crown regression coefficients & Estimate & $P$-value \\
\hline \multicolumn{3}{|l|}{ Street tree percent live crown (Adjusted R-squared $=0.0431$ ) } \\
\hline Tree age & 0.0075 & $<0.0001 * * *$ \\
\hline Ornamental trees & -0.0228 & $0.0384 *$ \\
\hline Group experience (\# trees planted as of planting year) & 0.0019 & 0.0577 \\
\hline Neighborhood resident groups & 0.0742 & $0.0093 * *$ \\
\hline Social service/non-profit groups & -0.0428 & $0.0405 *$ \\
\hline \multicolumn{3}{|l|}{ Yard tree percent live crown (Adjusted R-squared $=0.1398$ ) } \\
\hline Ornamental trees & -0.0391 & $0.0166 *$ \\
\hline Group longevity (\# years active as of planting year) & -0.0387 & $0.0004 * * *$ \\
\hline Group size (\# participants during planting year) & -0.0017 & $0.0135 *$ \\
\hline Tree age + Group longevity & 0.0037 & $0.0022 * *$ \\
\hline \multicolumn{3}{|l|}{ Park tree percent live crown (Adjusted R-squared $=0.2992$ ) } \\
\hline Group experience (total \# trees planted) & -0.0113 & $0.0315 *$ \\
\hline Group longevity (total \# years active) & 0.0521 & $<0.0001 * * *$ \\
\hline Group size (average \# participants) & 0.0191 & $0.0005 * * *$ \\
\hline Shade trees + Tree age & 0.0287 & 0.0506 \\
\hline \multicolumn{3}{|l|}{ Vacant lot tree percent live crown (Adjusted R-squared $=0.2004)$} \\
\hline Group experience (\# trees planted as of planting year) & 0.0093 & $0.0117 *$ \\
\hline Park groups & -0.1997 & $0.0181 *$ \\
\hline Social service/non-profit groups & 0.2000 & $0.0037 * *$ \\
\hline
\end{tabular}

groups), and in yard tree percent live crown. This finding supports work by Pagdee et al. (2006) and Wagner and FernandezGimenez (2009) indicating group size as a marker of stewardship success, at least within the context of urban forestry.

Certain group types were also recurring factors affecting tree survival and growth. Street trees planted by neighborhood resident groups had significantly improved growth, although the opposite was true among vacant lot trees. Conversely, social service/non-profit groups demonstrated improved growth among trees in vacant lots and yards, and significantly lower growth on streets. Park groups were effective in park plantings, with higher survival rates, but had low growth rates among vacant lot plantings. All of these findings support work by Millar (2003) that emphasizes the importance of participants feeling their work is in line with their mission so that they may be maximally effective. In support of Nowak's (1990) findings, public housing groups had lower survival of their yard trees than did other groups. However, yard trees planted by apartment groups actually had significantly higher survival rates, disputing findings by Nowak (1990) in that same paper.

Neighborhood characteristics, such as percent homeownership, and existing canopy cover accounted for a small portion of the variability in survival and growth as regarded by social factors. Percent homeownership was only significant in examining the survival of park and vacant lot trees, and findings were mixed on whether higher homeownership was a boon or a burden. Likewise, existing canopy cover was sometimes an indicator of improved mean annual growth increment (street trees) and in others diminished mean annual growth increment (ornamental park trees). Therefore the roles of neighborhood homeownership and existing canopy cover may require additional scrutiny in order to understand their contributions.

Many of the findings in this study underscore Abbott's (1995) assertion that factors affecting street tree mortality and health across community groups are complex. Rarely does a single factor account for a substantial amount of the variability seen in street tree survival and growth. Indeed, a single factor (such as group type or percent homeownership) can be a decidedly positive indicator in some situations and an apparently negative one in others. Therefore, while easily defined measures, such as group experience, size, longevity, or type, can offer valuable guidance on how to extend street tree investments, they are limited in how they define community groups composed of many different types of individuals. Only through more in-depth research, including interviews, could more comprehensive data on the impact of community groups on tree survival and growth be ascertained.

\section{CONCLUSIONS}

The most interesting findings of this study are that (a) social factors account for a small, albeit significant and important component of urban tree health, (b) community group experience, longevity, and size are frequently positively associated with improved tree survival and growth, (c) group types were most effective when planting in areas most in line with their focuses, and (d) percent homeownership and existing percent canopy cover played a limited role in the survival and growth of community-planted trees. Findings (b) and (c) supported the hypothesis and existing literature, while (d) went against predictions.

The most valuable management implication from this study is its insight into just how nuanced social factors affecting street tree survival and growth can be. This study supports existing literature indicating the importance of group experience, longevity, and size, but it also illustrates that no single social factor can guarantee successful stewardship.

Acknowledgments. We would like to thank The Urban Resources Initiative of Yale University/City of New Haven, Connecticut, for providing the original archived planting data, social assessment data, and for logistical guidance and advice in sampling. We thank The Hixon Center for Urban Ecology of the School of Forestry and Environmental Studies, Yale University for providing funding to carry out this study. 


\section{LITERATURE CITED}

Abbott, J. 1995. Community participation and its relationship to community development. Community Development Journal 30:158-168.

Anderson, L.M., and H.K. Cordell. 1988. Influence of trees on residential property values in Athens, Georgia (USA): A survey based on actual sales prices. Landscape Urban Planning 15:153-164.

Beatty, R.A., and C.T. Heckman. 1981. Survey of urban tree programs in the United States. Urban Ecology 5:81-102.

Black, M.E. 1978. Tree vandalism: some solutions. Journal of Arboriculture 4:114-116.

Boyce, S. 2010. It takes a stewardship village: Effect of volunteer tree stewardship on urban street tree mortality rates. Cities and the Environment $3: 1-8$

Burch, W.R., and J.M. Grove. 1993. People, trees and participation on the urban frontier. Unasylva 44:19-27.

Conrad, C.T., and T. Daoust. 2008. Community-based monitoring frameworks: increasing the effectiveness of environmental stewardship. Environment Management 41: 358-366.

Crawley, M.J. 2007. Getting Started, in The R Book. John Wiley \& Sons, Ltd. Chichester. 942 pp.

Dwyer J.F., D.J. Nowak, and G.W. Watson. 2002. Future directions for urban forestry research in the United States. Journal of Arboriculture 28:231-236.

Dwyer, J.F., E.G. McPherson, H.W. Schroeder, and R.A. Rowntree. 1992. Assessing the benefits and costs of the urban forest. Journal of Arboriculture 18:227-234.

Dwyer, J.F., G.M. Childs, and D.J. Nowak. 2000. Forestry in urban and urbanizing areas of the United States: Connecting people with ecosystems in the 21st century, pp. 629-637. In: B. Krishnapillay, E. Soepadmo, N. Arshad, A. Wong, S. Appanah, S. Chik, N. Manakaran, H. Trong, and K. Choon (Eds.). Forests and Society: The Role of Research. Sub-Plenary Sessions Vol 1. XXI IUFRO World Congress, August 7-12, 2000, Kuala Lumpur, Malaysia.

Florin P., D. Chavis, A. Wandersman, and R. Rich. 1992. A systems approach to understanding and enhancing grassroots organizations: The Block Booster Project, pp. 215-243. In: R.L. Levine and H.E. Fitzgerald (Eds.). Analysis of dynamic psychological systems, Vol. 2 : Methods and applications. Plenum Press, New York, New York, U.S.

Foster, R.S., and J. Blaine. 1978. Urban tree survival: Trees in the sidewalk. Journal of Arboriculture 4:14-17.

Greene, C.S., A.A. Millward, and B. Ceh. 2011. Who is likely to plant a tree? The use of public socio-demographic data to characterize client participants in a private urban forestation program. Urban Forestry \& Urban Greening 10:29-38.

Lee, M., and P. Hancock. 2011. Restoration and stewardship volunteerism, pp. 23-38. In: D. Egan, E.E. Hjerpe, and J. Abrams (Eds.). Human Dimensions of Ecological Restoration: Integrating Science, Nature, and Culture. Island Press, Washington, D.C., U.S.

Lohr, V.I., C.H. Pearson-Mims, J. Tarnai, and D.A. Dillman. 2004. How urban residents rate and rank the benefits and problems associated with trees in cities. Journal of Arboriculture 30:28-35.

Lu, J.W.T., E.S. Svendsen, L.K. Campbell, J. Greenfeld, J. Braden, K.L. King, and N. Falxa-Raymond. 2010. Biological, social, and urban design factors affecting young street tree mortality in New York City. Cities and the Environment 3(1). 15 pp.

Luley, C.J., and J. Bond. 2002. A plan to integrate management of urban trees into air quality planning. Davey Resource Group to North East State Foresters Association. 69 pp.

Maco, S.E., and E.G. McPherson. 2003. A practical approach to assessing structure, function, and value of street tree populations in small communities. Journal of Arboriculture 29:84-97.
McPherson, E.G., D.J. Nowak, and R.A. Rowntree. 1994. Chicago's Urban Forest Ecosystem: Results of the Chicago Urban Forest Climate Project. Gen. Tech. Report NE-186. US Department of Agriculture, Radnor, Pennsylvania.

McPherson, E.G., D.J. Nowak, G. Heisler, S. Grimmond, C.Souch, R. Grant, and R.A. Rowntree. 1997. Quantifying urban forest structure, function, and value: The Chicago Urban Forest Climate Project. Urban Ecosystems 1:49-61.

Millar, H. 2003. Successful stewardship and conservation organizations: Case studies and best practices. Commissioned Research for the Leading Edge: Stewardship \& Conservation in Canada. Canada: Land Trust Alliance of BC, Salt Spring Island, British Columbia.

Moskell, C., S.B. Allred, and G. Ferenz. 2010. Examining motivations and recruitment strategies for urban forestry volunteers. Cities and the Environment 3:9.

Nowak D.J., and E.J. Greenfield. 2012. Tree and impervious cover change in U.S. cities. Urban Forestry \& Urban Greening 11:21-30.

Nowak D.J., J.R. McBride, and R.A. Beatty. 1990. Newly planted street tree growth and mortality. Journal of Arboriculture 16:124-129.

Pagdee, A., Y.S. Kim, and P.D. Daugherty. 2006. What makes community forest management successful: A meta-study from community forests throughout the world. Society and Natural Resources 19:33-52.

Pelletier, K., and J. O'Neil-Dunne. 2009. A report on the city of New Haven's existing and possible urban tree canopy. Rubenstein School of the Environment \& Natural Resources, University of Vermont. United States Forest Service. 5 pp.

Quigley, M.F. 2004. Street trees and rural conspecifics: Will long-lived trees reach full size in urban conditions? Urban Ecosystems 7:29-39.

Ryan, R.L., R. Kaplan, and R.E. Grese. 2001. Predicting volunteer commitment in environmental stewardship programmes. Journal of Environmental Planning and Management 44:629-648.

Sanders R.A. 1984. Urban vegetation impacts on the urban hydrology of Dayton Ohio. Journal of Urban Ecology 9:361-376.

Sommer, R., F. Learey, J. Summit, and M. Tirrell. 1994. The social benefit of resident involvement in tree planting. Journal of Arboriculture 20:170-175.

Sullivan, W.C., and F.E. Kuo. 1996. Do trees strengthen urban communities, reduce domestic violence? Urban and Community Forestry Assistance Program Technology Bulletin No. 4. USDA Forest Service, Southern Region, Atlanta, Georgia.

Svendsen, E.S., and L.K. Campbell. 2008. Urban ecological stewardship: Understanding the structure, function and network of communitybased urban land management. Cities and the Environment 1:5.

Takano, T., K. Nakamura, and M. Watanabe. 2002. Urban residential environments and senior citizens' longevity in megacity areas. The importance of walkable green spaces. Journal of Epidemiology and Community Health 56:913-18

Taylor, A.F., and F.E. Kuo. 2011. Could exposure to everyday green spaces help treat ADHD? Evidence from children's play settings. Applied Psychology: Health and Well-Being 3:281-303.

Tomé, M., and H.E. Burkhart. 1989. Distance-dependent competitions measures for predicting growth of individual trees. Forest Science $35: 816-831$.

Troy, A., J.M. Grove, and J. O'Neil-Dunne. 2012. The relationship between tree canopy and crime rates across an urban-rural gradient in the greater Baltimore region. Landscaping and Urban Planning 106: $262-270$.

Wagner, C.L., and M.E. Fernandez-Gimenez. 2009. Effects of community-based collaborative group characteristics on social capital. Environmental Management 44:632-645. 
Wells, N.M. 2000. At home with nature: Effects of "greenness" on children's cognitive functioning. Environment and Behavior 32:775-795.

Westphal, L.E. 2003. Urban greening and social benefits: A study of empowerment outcomes. Journal of Arboriculture 29:137-147.

Westphal, L.M. 1993. Why trees? Urban forestry volunteers values and motivations. In: P.H. Golbster. 1993 Managing urban and high-use recreation settings. In: P.H. Golbster (Ed.). Fourth North American Symposium on Society and Resource Management. University of Wisconsin, Madison, Wisconsin, U.S.

Zhang, Y., A. Hussain, J. Deng, and M. Letson. 2007. Public attitudes towards urban trees and supporting urban tree programs. Environment and Behavior 39:797-814.

Emily Jack-Scott (corresponding author)

Yale School of Forestry \& Environmental Studies

195 Prospect Street

New Haven, Connecticut, 06511, U.S.

Urban Resources Initiative

Hixon Center for Urban Ecology

301 Prospect Street, First Floor

New Haven, Connecticut 06511, U.S.

emily.jackscott@gmail.com

Max Piana

Yale School of Forestry \& Environmental Studies 195 Prospect Street

New Haven, Connecticut, 06511, U.S.
Urban Resources Initiative

Hixon Center for Urban Ecology

301 Prospect Street, First Floor

New Haven, Connecticut 06511, U.S.

Blake Troxel

Yale School of Forestry \& Environmental Studies

195 Prospect Street

New Haven, Connecticut, 06511, U.S.

Urban Resources Initiative

Hixon Center for Urban Ecology

301 Prospect Street, First Floor

New Haven, Connecticut 06511, U.S.

Colleen Murphy-Dunning

Yale School of Forestry \& Environmental Studies 195 Prospect Street

New Haven, Connecticut, 06511, U.S.

Urban Resources Initiative

Hixon Center for Urban Ecology

301 Prospect Street, First Floor

New Haven, Connecticut 06511, U.S.

Mark S. Ashton

Yale School of Forestry \& Environmental Studies

195 Prospect Street

New Haven, Connecticut, 06511, U.S. 
Résumé. Au cours des deux dernières décennies, il y a eu une augmentation substantielle des plantations d'arbres de rues aux États-Unis. Plusieurs villes se sont fixées des objectifs ambitieux de plantation en comptant notamment sur les groupes communautaires de volontaires pour les réaliser. La recherche existante démontre que l'implication communautaire permet d'accroître le taux de survie des arbres de rues en milieu urbain. Il y a cependant un manque de recherche sur comment les caractéristiques des groupes communautaires affectent la survie et la croissance des arbres qu'ils ont planté. Cette étude explore la signification de la taille des groupes communautaires (nombre de participants), leur type (logements, surveillance de quartier, église, implication citoyenne, parc, résidents, école, services sociaux), la longévité de plantation (nombre d'années d'activité), le degré d'expérience (nombre d'arbres plantés) et le voisinage (limites géopolitiques). Les mesures se sont faites à partir de 1393 arbres plantés de 1995 à 2007 par 134 groupes via le programme d'Initiative en ressources urbaines des espaces verts communautaires à New Haven au Connecticut (États-Unis). Il y avait un taux global de survie de $76 \%$. Les plus hauts taux de survie et de croissance ont été obtenus des plantations par des groupes qui avaient plus d'expérience en plantation, une plus grande longévité et un plus grand nombre de participants. Des taux plus élevés de survie et de croissance étaient observés lorsque les arbres étaient plantés par des groupes travaillant en droite ligne avec leur mission propre (ex.: groupes de parc pour les parcs). Les taux les plus faibles de survie et de croissance ont été retrouvés parmi les arbres plantés en parterre par les groupes de résidents de maisons. Le couvert végétal existant et le pourcentage de propriétaires de maisons n'avait que peu d'influence sur les taux de survie et de croissance. Cette recherche constitue un guide pour les gestionnaires de villes en leur signifiant quels sont les groupes de plantation qui requièrent une assistance particulière pour mener avec succès des plantations d'arbres de rues qui sont durables.

Zusammenfassung. Während der letzten zwei Dekaden hat eine einen deutliche Anstieg der Straßenbaumpflanzungen in den USA gegeben. Viele Städte haben sich ambitionierte Ziele gesetzt und setzten dabei auf freiwillige kommunale Gruppen, um diese zu unterstützen. Die existierende Forschung zeigt, dass eine kommunale Patenschaft das Überleben der Straßenbäume steigert. Dennoch besteht ein Forschungsbedarf darin, die Charakteristiken zu definieren, wie diese Gruppen das Überleben und Wachstum der Pflanzen beeinflussen. Diese Studie erforscht die Bedeutung der Gruppengröße (\# Teilnehmer), Typ (\# Apartment, Häuserblock, Kirche, betroffene Nachbarn, Park, soziale Wohnungen, Schule, Sozialdienst), Pflanzdauer (\# aktive Jahre), Erfahrungsgrad (\# gepflanzte Bäume) und Nachbarschaft (\# geopolitische Grenzen). Für diese Studie wurden 1393 Bäume, die zwischen 1995 bis 2007 durch 134 Gruppen durch das Urban Resources Initiative's Community Greenspace program in New Haven, Connecticut, U.S. gemessen. Es gab eine allgemeine Überlebensrate von $76 \%$. Die höchste Überlebensrate und Wachstum wurde bei Gruppen gefunden, die mehr Pflanzerfahrung, mehr aktive Jahre und mehr Teilnehmer hatten. Höhere Überlebens- und Wachstumsraten wurden beobachtet, wenn die Bäume von Leuten mit Bezug zu ihrer Mission (z.B. Parkbäume von Parkanwohnern) gepflanzt wurden. Die niedrigsten Überlebens- und Wachstumsraten fanden wir bei Hofbäumen von Sozialwohnsiedlungen. Die existierende Kronenfläche und der Prozentsatz an nachbarschaftlichen Hauseigentümern hatte nur geringen Einfluss auf Überleben oder Wachstum. Diese Forschung kann einen Leitfaden für Stadtverwalter sein, indem sie Vorschläge liefert, welche Pflanzgruppen welche Assistenz zur erfolgreichen Durchführung von langlebigen Baumpflanzungen benötigen.

Resumen. En las últimas dos décadas ha habido un aumento sustancial en la plantación de árboles urbanos en todo Estados Unidos. Muchas ciudades han establecido objetivos ambiciosos de plantación, dependiendo de la participación de los grupos voluntarios de la comunidad La investigación existente demuestra que la administración comunitaria aumenta la supervivencia de los árboles urbanos. Hay una falta de investigación, sin embargo, sobre cómo las características de los grupos de la comunidad afectan la supervivencia y el crecimiento de los árboles que ellos plantan. Este estudio explora la importancia del tamaño del grupo de la comunidad (\# participantes), tipo (apartamento, iglesia, vecinos preocupados, parque, vivienda pública, escuela y servicios sociales), la longevidad de la plantación (\# años activo), nivel de experiencia (\# árboles plantados), y el vecindario (fronteras geopolíticas). Las medidas en este estudio fueron para 1393 árboles plantados desde 1995 hasta 2007 , por 134 grupos, a través del programa Urban Resources Initiative's Community Greenspace en New Haven, Connecticut, EE.UU. Hubo una tasa de supervivencia global del $76 \%$. Se encontró mayor supervivencia y el crecimiento de los árboles plantados por los grupos con más experiencia en la plantación, mayor longevidad y más participantes. Se observó mayor supervivencia y crecimiento cuando los árboles fueron plantados por los grupos de trabajo de acuerdo con su misión (por ejemplo, grupos en los parques). Se encontró la supervivencia y el crecimiento más bajo en árboles plantados por los grupos de vivienda pública. La cobertura del dosel existente y el porciento propiedad de la vivienda tuvieron poco efecto sobre la supervivencia o el crecimiento. Esta investigación puede ofrecer una guía para los administradores de la ciudad por lo que sugiere que los grupos de plantación requieren asistencia especial para llevar a cabo con éxito las plantaciones de árboles en las calles. 